\title{
Bryonia dioica aqueous extract induces apoptosis and G2/M cell cycle arrest in MDA-MB 231 breast cancer cells
}

\author{
BACHIR BENARBA $^{1}$, ALMAHY ELMALLAH ${ }^{2}$ and ATANASIO PANDIELLA ${ }^{3}$ \\ ${ }^{1}$ Laboratory Research on Biological Systems and Geomatics, Faculty of Nature and Life, \\ University of Mascara, Mascara 29000, Algeria; ${ }^{2}$ Zoology Department, Faculty of Science Beni-Suef University, \\ Beni-Suef 62511, Egypt; ${ }^{3}$ Instituto de Biología Molecular y Celular del Cáncer, \\ CSIC-CIBERONC-Universidad de Salamanca, 37001 Salamanca, Spain
}

Received June 29, 2018; Accepted March 1, 2019

DOI: $10.3892 / \mathrm{mmr} .2019 .10220$

\begin{abstract}
Bryonia dioica Jacq. is a climbing perennial herb with tuberous roots which is widely used in traditional medicine in Algeria for the treatment of cancer. The present study aimed to evaluate the apoptogenic activity and phytochemical composition of the aqueous extract of $B$. dioica roots growing in Algeria. The cytotoxic effect of $B$. dioica aqueous decoction against breast cancer MDA-MB-231 cells was evaluated by an MTT assay. Apoptosis induction was assessed by an Annexin V-fluorescien iosthiocyanate assay. Propidium iodide staining of cell DNA was used to assess the effects on the cell cycle. In addition to UV-Visible (UV-vis) analysis, the major compounds of the extracts were determined using liquid chromatography-mass spectrometric analyses. Our results showed that the B. dioica aqueous extract induced cell death in a time-dependent manner. The highest inhibitory effect was produced at concentrations of $50 \mu \mathrm{g} / \mathrm{ml}$ or higher after $72 \mathrm{~h}$ of treatment $(91.15 \pm 0.71 \%)$. Furthermore, the extract induced apoptosis of MDA-MB-231 cells. At $250 \mu \mathrm{g} / \mathrm{ml}$, $64.61 \%$ of the treated MDA-MB-231 cells were apoptotic. This was accompanied by cell cycle arrest at G2/M phase. The percentage of cells in $\mathrm{G} 2 / \mathrm{M}$ increased from $15.7 \%$ (untreated cells) to $59.13 \%(50 \mu \mathrm{g} / \mathrm{ml})$ and $58.51 \%(250 \mu \mathrm{g} / \mathrm{ml})$. The $\mathrm{UV}$-vis absorption spectra of $B$. dioica aqueous extract showed two absorption bands characteristic of the flavonol skeleton; 350-385 nm (Band I) and 250-280 nm (Band II). Myricetin (2,5,7,3,4,5-pentahydroxylflavonol) was found to be the major compound in the $B$. dioica aqueous extract. These findings suggest that $B$. dioica could be considered a promising source for developing novel therapeutics against breast cancer.
\end{abstract}

Correspondence to: Dr Bachir Benarba, Laboratory Research on Biological Systems and Geomatics, Faculty of Nature and Life, University of Mascara, B.P 305 Route de Mamounia, Mascara 29000, Algeria

E-mail: bachirsb@yahoo.fr

Key words: Bryonia dioica, MDA-MB-231, breast cancer, apoptosis, cell cycle, flavonols, myricetin

\section{Introduction}

Breast cancer, considered heterogeneous cancer, both biologically and molecularly, is the most common malignancy in women worldwide (1). Breast cancer still remains the first cause of cancer-related deaths among women, especially in developing countries in which $60 \%$ of breast cancer-related deaths are reported (2). In spite of being treated by different therapeutic approaches including chemotherapy, radiotherapy, surgery, hormone therapy and other targeted therapies, breast cancer is facing important issues such as high long-term mortality, drug-resistance, and metastases (3). Thus, search for effective alternative therapies with fewer side effects has become necessary.

In Africa, up to $80 \%$ of the population uses traditional medicine for primary health care (4). Algeria, the biggest African country with a large variety of soils (littoral, steppe, mountains, and desert) and climates, possesses a rich flora (more than 3,000 species and 1,000 genders) (5). In Algeria, many patients use medicinal plants as a treatment for many ailments and serious diseases, such as cancer, diabetes and arterial hypertension, for several considerations: Historical, cultural and economic (6-8). Although few studies have been published on ethnobotanical and pharmacological properties of Algerian medicinal plants, several species have been found to be used by Algerian breast cancer patients such as Aristolochia longa L., Berberis vulgaris L., Thymus vulgaris L., Prunus persica (L.) Batsch, and Artemisia herba-alba L. (9). Previously, we have demonstrated that aqueous extracts of Aristolochia longa roots, an Algerian medicinal plant widely used in cancer therapy by local populations, induced apoptosis of Burkitt's lymphoma BL41 cell line by targeting the mitochondrial pathway (10). An aqueous extract of Aristolochia longa induced cell growth inhibition in HBL100 and MDA-MB-231 triple negative breast cancer cells in a dose-dependent manner (11). Other extracts of Aristolochia longa aerial parts exhibited promising antioxidant and anticancer activities in different cell lines (data not published).

Bryonia dioica Jacq. (white bryony) a climbing perennial herb with tuberous roots is locally named in Algeria 'Fachira' and 'queriou'aa' by the locals. The species grows in North Africa, temperate Europe, and Western Asia (12). 
The roots of $B$. dioica are characterized by the presence of cucurbitacins, oxygenated tetra-cyclic triterpenoids possessing anti-inflammatory, anti-infectious, cytotoxic and apoptogenic effects $(9,13)$. The plant is used to treat several ailments such as asthma, bronchitis, hypertension, gastric ulcers, and diabetes (14). Important biological and therapeutic effects of $B$. dioica were demonstrated such as antidiabetic (15), antibacterial (16) and antioxidant activities (17). The plant possesses also important anticancer activities. Indeed, we have previously shown that $B$. dioica aqueous extract induced apoptosis in Burkitt's lymphoma BL41 cell line by triggering the intrinsic pathway (18). Besides, $B$. dioica aqueous extracts exhibited promising cytotoxic activities against different blood and breast cancer cell lines (data not published).

As part of our continuing work to evaluate the anticancer activity of Algerian medicinal plants used in cancer treatment, the present study aimed to evaluate apoptogenic activity and identify the major bioactive compound of B. dioica.

\section{Materials and methods}

Reagents. Cell culture media, 3-(4,5-dimethylthiazol-2-yl) -2,5-diphenyltetrazolium bromide (MTT) and Propidium iodide were purchased from Sigma-Aldrich (St. Louis, MO, USA). Annexin V-FITC was from BD Biosciences (Franklin Lakes, NJ, USA). The other generic chemicals were from Sigma-Aldrich, Roche Applied Science (Mannheim, Germany) or Merck KGaA, Darmstadt, Germany.

Cells and culture conditions. The human triple-negative breast cancer MDA-MB-231 cell line was obtained from the American Type Culture Collection (ATCC; Manassas, VA, USA). The cells were cultured in DMEM medium with Glutamax supplemented with $10 \%$ FCS, $100 \mathrm{U} / \mathrm{ml}$ penicillin and $100 \mu \mathrm{g} / \mathrm{ml}$ streptomycin, in a humidified atmosphere with $5 \% \mathrm{CO}_{2}$ in air at $37^{\circ} \mathrm{C}$. The experiments were performed three times using cells in the exponential growth phase.

Preparation of B. dioica aqueous extract. The roots of $B$. dioica were collected in March 2012 in Mascara, Algeria. Botanical identification and authentication were done by Dr Kada Righi (Department of Agriculture, Faculty of Nature and Life sciences, Mascara University, Mascara, Algeria). A voucher specimen of the plant (voucher no. LRSBG/B-2012/003) was deposited in the herbarium of the laboratory, Department of Biology, Faculty of Nature and Life sciences, Mascara University, Mascara, Algeria. The collected roots were dried at room temperature, pulverized and finely sieved. The $B$. dioica aqueous extract was prepared as follows: the dried roots were boiled for $20 \mathrm{~min}$ at $100^{\circ} \mathrm{C}$, cooled to room temperature, and then filtered. The filtered solution was collected, concentrated, lyophilized and stored in a desiccator at $+4^{\circ} \mathrm{C}$ until used.

MTT (3-(4,5-dimethylthiazol-2-yl)-2,5-diphenyltetrazolium bromide) tetrazolium reduction assay. The effects of the B. dioica aqueous extract on MDA-MB-231 cells viability were determined by the colorimetric MTT assay. Briefly, MDA-MB-231 cells were seeded at a density of $8 \times 10^{3}$ cells/well in 96 -well plates and incubated for $24 \mathrm{~h}$ at $37^{\circ} \mathrm{C}$. Thereafter, cells were treated with increasing concentrations (from 0 to
$500 \mu \mathrm{g} / \mathrm{ml}$ ) of B. dioica aqueous extract for 24,48 , and $72 \mathrm{~h}$. At the end of the treatment, $50 \mu \mathrm{l}$ of MTT $(0.5 \mathrm{mg} / \mathrm{ml})$ was added and the cells were incubated at $37^{\circ} \mathrm{C}, 5 \% \mathrm{CO}_{2}$ for $1 \mathrm{~h}$. After medium removal, $500 \mu \mathrm{l}$ of DMSO was added to each well to dissolve the formazan formed during the reaction and the plate was then shaken for $10 \mathrm{~min}$ under obscurity. The absorbance was recorded at $570 \mathrm{~nm}$ using a 96-well plate reader (ASYS-UVM-340). All the experiments were performed in triplicate.

Detection of apoptosis-Annexin V-FITC/PI staining. Apoptosis induction was assessed using the Annexin V-FITC assay. Briefly, MDA-MB-231 were treated with 50 and $250 \mu \mathrm{g} / \mathrm{ml}$ of $B$. dioica aqueous extract for 48 h. Cells were harvested, re-suspended in the ice-cold $1 \mathrm{x}$ binding buffer, and then incubated with Annexin V-FITC and PI solutions for $15 \mathrm{~min}$ at room temperature in the dark. After incubation, the cells were analyzed using FACSCalibur, BD Biosciences (19).

Cell cycle analysis. Following exposure to $B$. dioica aqueous extract (50 and $250 \mu \mathrm{g} / \mathrm{ml}$ ) for $48 \mathrm{~h}$, MDA-MB-231 cells were collected and fixed with cold $70 \%$ ethanol and stored overnight at $-20^{\circ} \mathrm{C}$. Cells were washed, re-suspended in PBS and incubated at $37^{\circ} \mathrm{C}$ for $30 \mathrm{~min}$ with $10 \mathrm{mg} / \mathrm{ml} \mathrm{RNase}$ and $1 \mathrm{mg} / \mathrm{ml}$ propidium iodide (PI). DNA content was then determined using a FACSCalibur flow cytometer (BD Biosciences) (20).

$U V$-vis analysis. UV-vis analysis of $B$. dioica aqueous extract was performed on a Shimadzu spectrophotometer $(\lambda=200-800 \mathrm{~nm})$ as described by (21). The absorption peak values were recorded.

Chromatographic analyses. To determine the major compounds in the B. dioica aqueous extract, we performed liquid chromatography-mass spectrometric analyses using HPLC Agilent 1100 (Agilent Technologies GmbH, Waldbronn, Germany) coupled to an ultraviolet detector and to an Agilent Trap XCT mass spectrometer equipped with an electrospray (ESI) source with a nebulizer spacer as previously described (22).

Statistical analysis. Mean data values are presented, with their standard deviations (mean $\pm \mathrm{SD}$ ). The statistical comparisons were made by one-way analysis of variance followed by Bonferroni's post-hoc test. $\mathrm{P}<0.05$ was considered to indicate a statistically significant difference.

\section{Results}

$B$. dioica aqueous extract induced cell growth inhibition of $M D A-M B-231$. In the present study, we investigated the effects of an aqueous extract of $B$. dioica roots on cell viability in vitro, by incubating MDA-MB-231 cells with increasing concentrations (from 0 to $500 \mu \mathrm{g} / \mathrm{ml}$ ) of the extract. After 24 , 48 and $72 \mathrm{~h}$, cell viability was determined by the colorimetric MTT assay. We determined survival as a percentage of that for untreated cells. As shown in Fig. 1, B. dioica aqueous extract induced cell growth inhibition in a time-dependent manner. At $50 \mu \mathrm{g} / \mathrm{ml}$, B. dioica aqueous extract resulted in 50.36, 72.39 and $91.15 \%$ inhibition of cell viability of MDA-MB-231 cells after 24,48 and $72 \mathrm{~h}$, respectively. 


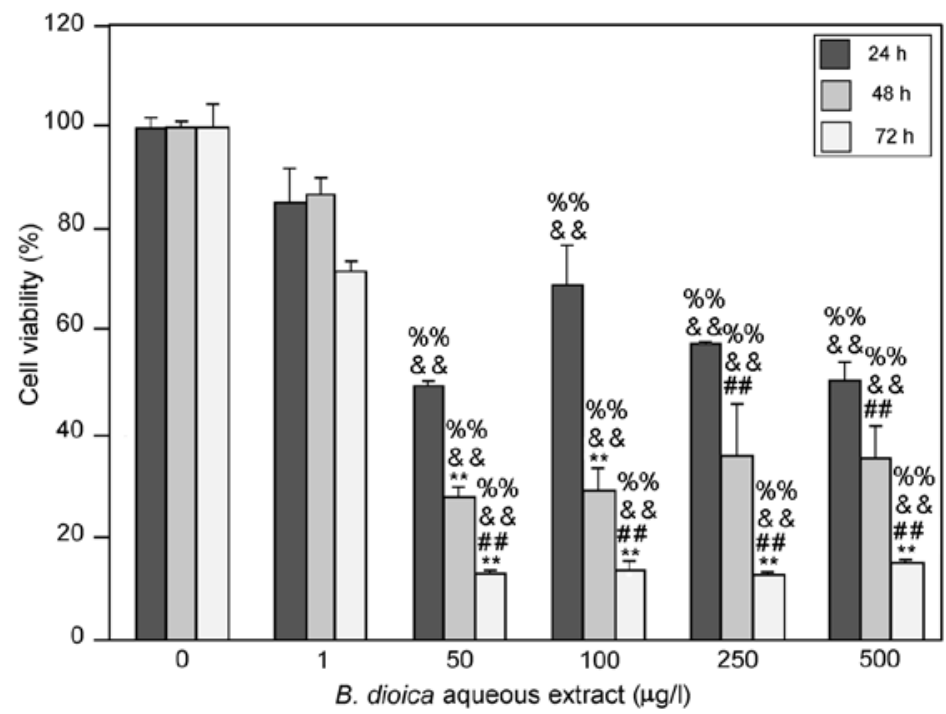

Figure 1. Effect of $B$. dioica aqueous extract on viability of MDA-MB231 cells. Cells were treated with increasing concentrations (between 0.00 and $500 \mu \mathrm{g} / \mathrm{ml}$ ) of $B$. dioica aqueous extract for 24, 48 and $72 \mathrm{~h}$; cell viability was measured by an MTT assay. Percentage of survival was determined as compared with the untreated cells. The experiments were performed in quadruplicate. Statistical comparisons were using the one-way analysis of variance followed by Bonferroni's post hoc test. ${ }^{* *} \mathrm{P}<0.01$ vs. respective $24 \mathrm{~h} ;{ }^{\# \#} \mathrm{P}<0.01$ vs. respective $48 \mathrm{~h}$; ${ }^{\& \&} \mathrm{P}<0.01$ vs. respective group at $0 \mu \mathrm{g} / \mathrm{ml}$ B. dioica; ${ }^{\% \%} \mathrm{P}<0.01 \mathrm{vs} .1 \mu \mathrm{g} / \mathrm{ml}$ B. dioica.

The highest inhibitory effect was produced at concentrations of $50 \mu \mathrm{g} / \mathrm{ml}$ or higher after $72 \mathrm{~h}$ of treatment $(91.15 \pm 0.71 \%)$. Interestingly, this effect remains unchanged at higher concentrations $(100,250$ and $500 \mu \mathrm{g} / \mathrm{ml})$.

B. dioica aqueous extract induced apoptosis of MDA-MB-231. We then investigated whether this decrease in cell viability was associated with the induction of apoptosis by incubating MDA-MB-231 cells with 50 and $250 \mu \mathrm{g} / \mathrm{ml}$ of $B$. dioica aqueous extract for $48 \mathrm{~h}$. The apoptotic cell death rate was estimated with Annexin V-FITC and PI double staining by flow cytometry. The results showed that $B$. dioica aqueous extract induced MDA-MB-231 apoptosis in a dose-dependent manner (Fig. 2). Indeed, apoptotic cells elevated significantly from 38.95 to $64.61 \%$ of the MDA-MB-231 cells exposed to 50 and $250 \mu \mathrm{g} / \mathrm{ml}$, respectively. However, the apoptosis rate in untreated cells was only $0.68 \%$.

B. dioica aqueous extract induced cell cycle arrest of $M D A-M B-231$. To examine the effect of $B$. dioica aqueous extract on the cell cycle progression, MDA-MB-231 cells were incubated for $48 \mathrm{~h}$ in the absence or presence of 50 and $250 \mu \mathrm{g} / \mathrm{ml}$ of the extract. Cell nuclei were stained with PI and the percentage of cells in each phase of the cell cycle were determined by flow cytometry. As shown in Fig. 3, our data revealed that treatment with $B$. dioica aqueous extract caused cell cycle arrest of MDA-MB-231 cells at G2/M phase. In fact, the percentage of cells in $\mathrm{G} 2 / \mathrm{M}$ increased from $15.7 \%$ (untreated cells) to $59.13 \%(50 \mu \mathrm{g} / \mathrm{ml})$ and $58.51 \%(250 \mu \mathrm{g} / \mathrm{ml})$. Moreover, $B$. dioica aqueous extract resulted in a dose-dependent decrease in the population of cells in the G0/G1 phase from $65.82 \%$ (untreated cells) to 23.00 , and $11.80 \%$ after treatment with 50 and $250 \mu \mathrm{g} / \mathrm{ml}$, respectively.

Major compounds of B. dioica aqueous extract. The UV-vis spectrum of $B$. dioica aqueous extract was characterized by two major absorption bands: 350-385 nm (Band I, cinnamoyl system) and 250-280 nm (Band II, benzoyl system), corresponding to flavonol structure.

As shown in Fig. 4, peak 2 corresponded to the major compound found in the $B$. dioica extract. This compound was detected at $2.3 \mathrm{~min}$ of retention time and represented $75.3 \%$ of the extract.

The MS spectra (Fig. 5) of the major compound (peak 2) showed a molecular ion of $\mathrm{m} / \mathrm{z}=318.5$ and two main fragments $(\mathrm{m} / \mathrm{z}=230.4$ and 274.5). According to the obtained data (Table I) and in comparison with literature, we suggest that the major compound in B. dioica aqueous extract could be myricetin (Fig. 6).

\section{Discussion}

Natural products provide an appreciable percentage of new active lead molecules, and drugs despite competition from different methods of drug discovery (23). Medicinal plants constitute a common alternative for cancer treatment by providing cytotoxic and apoptogenic agents (24-27). We have previously found that the aqueous extract of $B$. dioica roots exerted a promising anticancer activity against Burkitt's lymphoma BL41 cells. This cytotoxic effect was accompanied by the induction of apoptosis (18). Likewise, we have demonstrated that the extract was able to inhibit different cancer cell lines growth including those of multiple myeloma, lymphoma and triple negative breast cancer (data not published). In the current study, we showed that $B$. dioica aqueous extract induced cell growth inhibition of breast cancer MDA-MB-231 cells in a time-dependent manner. At $50 \mu \mathrm{g} / \mathrm{ml}$, the extract suppressed effectively the proliferation of MDA-MB-231 cells (91.15\% inhibition of proliferation) after 72 h. Recently, Sahpazidou et al (28) evaluated the cytotoxic effects of polyphenolic extracts from grape stems against various cancer cell lines (breast, kidney, colon, and thyroid). After $72 \mathrm{~h}$ of treatment, MDA-MB-231 cells were the most sensitive to all 

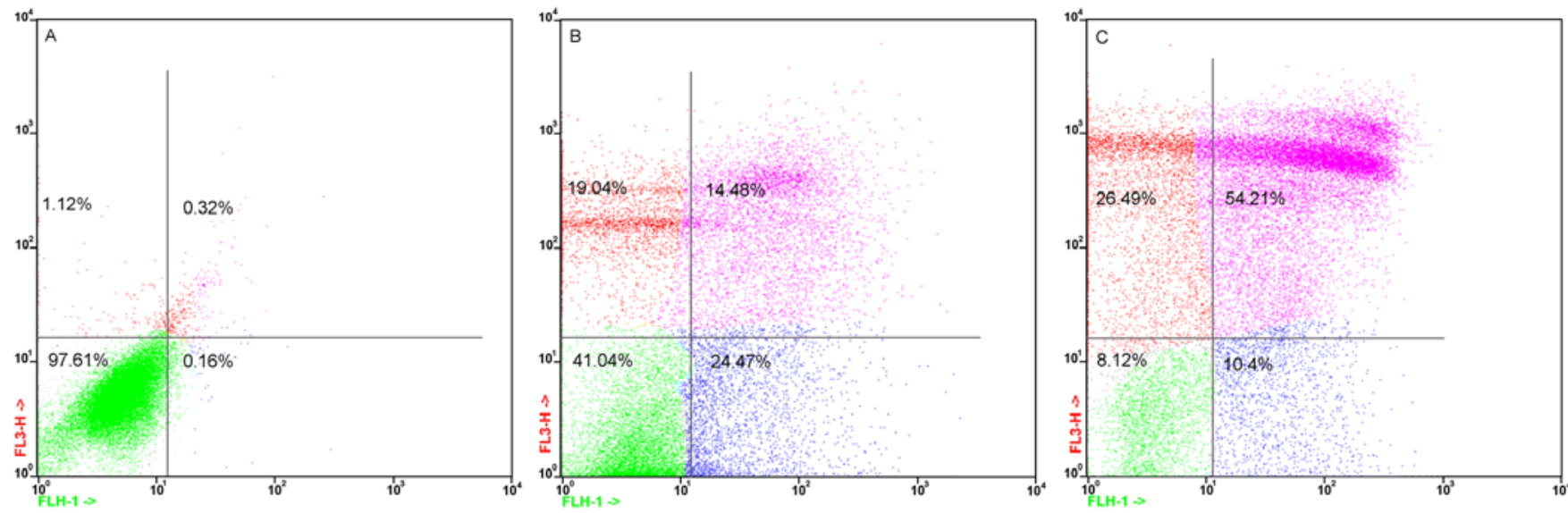

Figure 2. Apoptosis induction in MDA-MB-231 by B dioica aqueous extract as assessed by Annexin V/PI assay. Apoptosis in (A) control cells, and cells treated with (B) 50 and (C) $250 \mu \mathrm{g} / \mathrm{ml}$ B. dioica. Viable cells are AnnexinV-and PI-, early apoptotic cells are Annexin V+ and PI-, and late apoptotic cells are Annexin $\mathrm{V}+$ and PI+. The experiments were performed in triplicate. PI, propidium iodide.

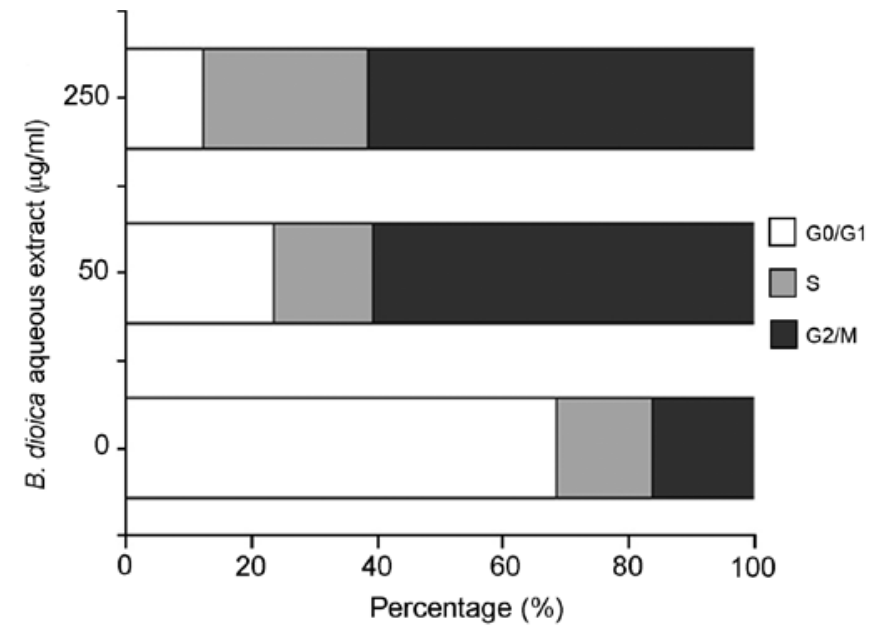

Figure 3. Effect of $B$. dioica aqueous extract on cell cycle progression. MDA-MB-231 cells were treated for $48 \mathrm{~h}$ with 50 and $250 \mu \mathrm{g} / \mathrm{ml}$ of $B$. dioica aqueous extract. Cell cycle analysis was conducted following propidium iodide staining. The experiments were performed in triplicate.

tested extracts, with $\mathrm{IC}_{50}$ values of 120 and $184 \mu \mathrm{g} / \mathrm{ml}$. We then investigated the apoptotic effects of $B$. dioica aqueous extract in MDA-MB-231 cells.

Apoptosis is one of the main types of programmed cell death and can be triggered by a variety of stimuli received by the cells (29). Induction of apoptosis in the activated cancer cells may be an effective strategic approach for cancer therapy (30). We examined the induction of apoptosis with Annexin V-FITC and PI double staining by flow cytometry. Our results showed that the proportion of apoptotic cells significantly elevated in MDA-MB-231 (50 and $250 \mu \mathrm{g} / \mathrm{ml}$ )-treated cells from $0.68 \%$ in untreated cells to 35.95 and $64.61 \%$, respectively. These results are in agreement with our previous study demonstrating that the $B$. dioica aqueous extract was able to induce apoptosis of Burkitt's lymphoma BL41 cells in a dose-dependent manner. Apoptosis induction was accompanied by triggering the intrinsic pathway (activation of caspase-3 and -9, cleavage of PARP and loss of mitochondria membrane potential) (18). Moreover, it has been demonstrated that several herbal extracts caused MDA-MB-231 cells growth inhibition through apoptosis induction at high concentrations $(31,32)$. Our data showed that $B$. dioica aqueous extract was able to induce marked apoptosis at a lower concentration $(50 \mu \mathrm{g} / \mathrm{ml})$ in MDA-MB-231 cells, which are known to be resistant to apoptosis (33).

Generally, cell cycle arrest and induction of apoptosis are connected, an occurrence of cell cycle arrest leads to cell apoptosis (34). In the present study, the progression of cell cycle was assessed by propidium iodide (PI) staining of cell DNA after incubation of cells with $B$. dioica aqueous extract. Besides apoptosis induction, the cytotoxic effect caused by $B$. dioica aqueous extract was further due to a cell cycle arrest of MDA-MB-231 cells at G2/M phase. In fact, treatment with $B$. dioica aqueous extract resulted in an accumulation of MDA-MB-231 cells in the G2/M phase (15.7\% of untreated cells vs. $59.1 \%$ of treated cells with $50 \mu \mathrm{g} / \mathrm{ml}$ ). This effect may be attributed to the presence of flavonols (major compounds in the extract). It has been demonstrated that flavonols such as quercetin or kaempferol induce G2/M phase cell cycle arrest in different cancer cell lines (35). Zhang et al (36) demonstrated that three flavonols (Kaempferol, quercetin, and myricetin) exerted cytotoxic effects on a human oesophageal adenocarcinoma cell line (OE33) by inducing G2/M arrest. Similarly, quercetin, myricetin, laricitrin, and syringetin were capable of inhibiting the proliferation of colorectal epithelial adenocarcinoma cells via cell cycle arrest in the G2/M phase (37).

Taken together, our data demonstrate that $B$. dioica aqueous extract-mediated inhibition of MDA-MB-231 cell growth may be the result of apoptosis induction and cell-cycle arrest in the $\mathrm{G} 2 / \mathrm{M}$ phase.

The UV-vis absorption spectra of B. dioica aqueous extract showed two absorption bands characteristic of flavonol skeleton, 350-385 nm (Band I) and 250-280 nm (Band II) indicating that the major compounds in the extract are flavonols (38). Flavonols are characterized by fully unsaturated C-rings that connect the $\mathrm{A}$ and $\mathrm{B}$ rings in a single conjugated system. All flavonoids have aromatic chromophores, as indicated by UV absorptions in the $250 \mathrm{~nm}$ region of their UV spectra (Band B) (39). Band A lies in the 350-385 nm range for flavonols (40). Flavonols, considered as the strongest antioxidant flavonoids, exhibit important antioxidant activity, mainly based on scavenging of oxygen radicals (41). Moreover, 


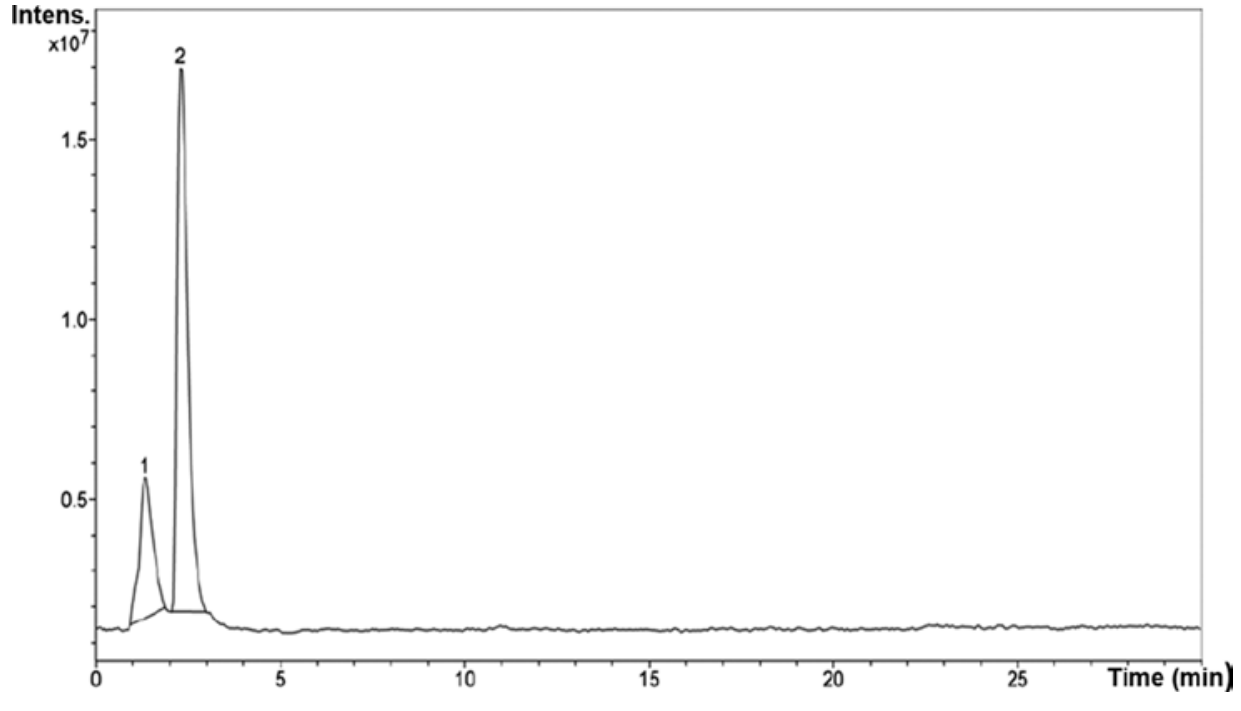

Figure 4. High-performance liquid chromatogram of $B$. dioica extract (254 nm).
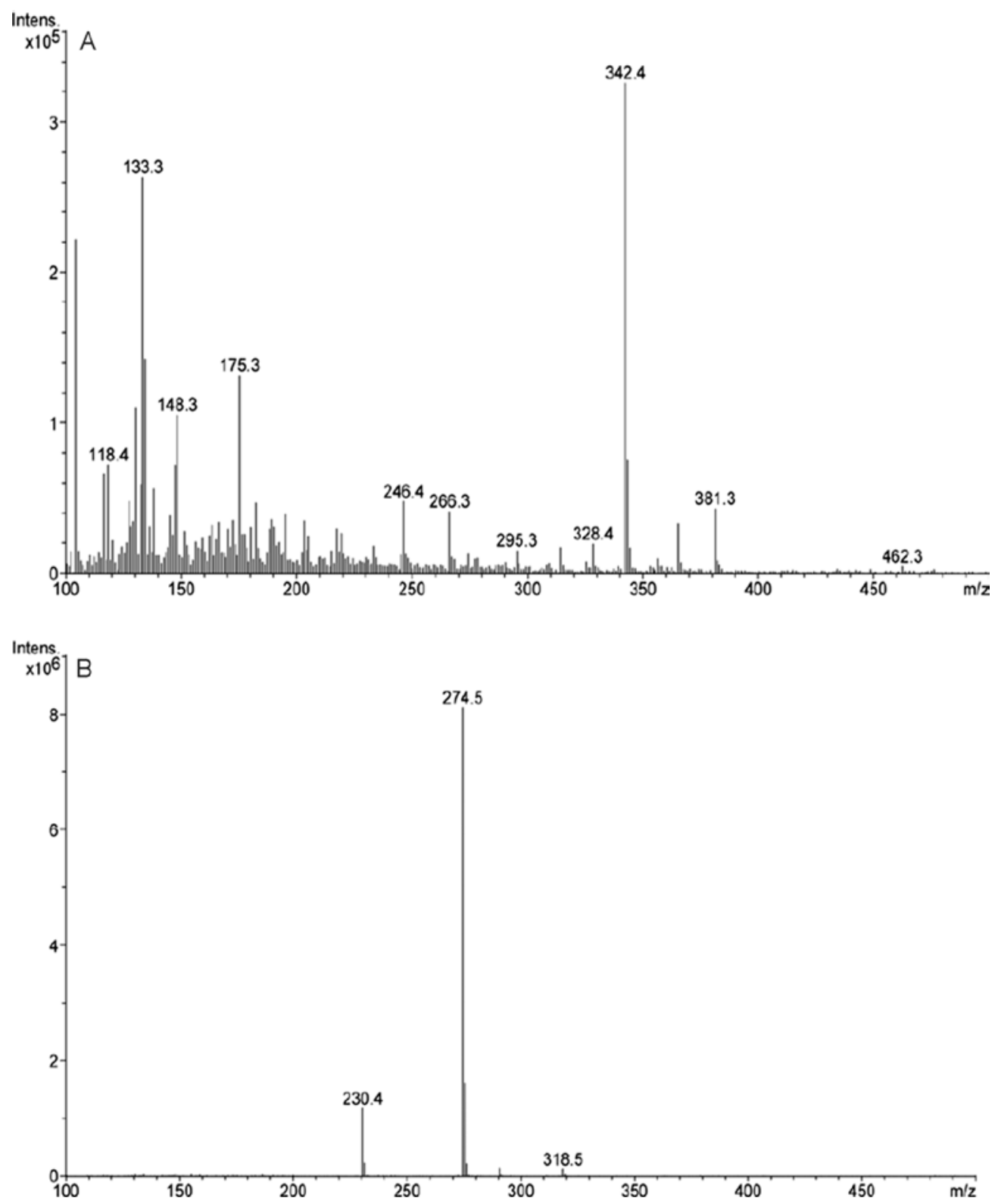

Figure 5. Mass spectroscopy of B. dioica. (A) MS spectra corresponding to the peak found at Rt=1.3 min. (B) MS spectra corresponding to the peak found at $\mathrm{Rt}=2.3 \mathrm{~min}$. MS, mass spectrometry. 
Table I. Compounds identified in B. dioica aqueous extract in positive-ion mode.

\begin{tabular}{lccccc}
\hline Peak number & RT, min & Area fraction percentage & $(\mathrm{M}-\mathrm{H})+(\mathrm{m} / \mathrm{z})$ & $\mathrm{MS}^{2}$ Characteristic ions (m/z) & Compound \\
\hline 1 & 1.3 & 24.7 & - & - & - \\
2 & 2.3 & 75.3 & 318.5 & $318.5,274.5,230.4$ & Myrecitin \\
\hline
\end{tabular}<smiles>O=c1c(O)c(-c2cc(O)c(O)c(O)c2)oc2cc(O)cc(O)c12</smiles>

Figure 6. Chemical structure of myricetin.

their increased intake has been correlated with a reduced risk of various cancers such as ovarian, breast, prostate, lung and liver cancers (42). These cancers were found to be of the most frequent malignancies in Algeria. Previously, Barros et al (2011) (43) reported the presence of one flavonol in B. dioica roots: Kaempferol 3, 7-di-O-rhamnoside. Kaempferol has been demonstrated to possess anticancer and apoptogenic activity against a variety of cancer cell lines such as myelogenous leukemia cell line K562, promyelocytic human leukemia U937 (44), Human lung non-small carcinoma H460 cell line (45), breast cancer MDA-MB-231 cell line (46) and oral cancer cell lines (SCC-1483, SCC-25 and SCC-QLL1) (47).

In the present study, we identified Myricetin (2,5,7,3,4,5-pentahydroxylflavonol) as the major compound in $B$. dioica aqueous extract. Myricetin the most common flavonoid found in herbs, vegetables, and fruits, has been shown to possess important biological activities including antioxidant, antimicrobial, antidiabetic and anticarcinogenic effects (48). Anticancer and apoptogenic activities of myricetin have been demonstrated against several cancers such as colorectal cancer (49), ovarian cancer $(50,51)$, leukemia (52) or lung cancer (53). Furthermore, it has been reported that myricetin was able to cause cell death in different cancer cell lines by arresting the cell cycle at different phases (54). In fact, Myricetin arrested the cell cycle of cancer cells by triggering CDKs and cyclins $(55,56)$.

Myricetin was found to be the major component in different herbal extracts inducing apoptosis and/or cell cycle arrest in human breast cancer cells (57). In vivo, myricetin was found to be more effective than vincristine in chemoprevention of dimethyl benzanthracene-induced-breast cancer in female Wistar rats (58). Interestingly, myricetin was not cytotoxic towards normal breast cells, justifying its ability to be considered for in vivo studies (59).

Recently, a second-generation myricetin analog: Oncamex has been demonstrated to induce apoptosis and cell cycle arrest in MCF-7, MDA-MB-231, BT-549 and HBL-100 breast cancer cell lines. In addition, the myricetin analog exhibited important anti-breast cancer activity in mice implanted with MDA-MB-231 xenografts (60).

In conclusion, we demonstrate a strong cytotoxic effect of the $B$. dioica aqueous extract against breast cancer MDA-MB-231 cells line. B. dioica aqueous extract was able to induce marked apoptosis and cell cycle arrest at $\mathrm{G} 2 / \mathrm{M}$ phase of MDA-MB-231 cells at a lower concentration $(50 \mu \mathrm{g} / \mathrm{ml})$. The phytochemical study (UV-vis and LC-MSD-Trap-XCT) revealed the presence of myricetin as the major compound that may contribute to the apoptogenic activity of the $B$. dioica aqueous extract. Thus, B. dioica could be considered as a promising source for developing novel therapeutics against breast cancer.

\section{Acknowledgements}

The authors would like to thank Mrs Susana Hernandez (Centro de Investigación del Cáncer, Salamanca, Spain) for technical assistance.

\section{Funding}

BB received funding for a short-term internship from the Algerian Ministry of Higher Education and Scientific Research. The study was supported by CSIC-CIBERONCUniversidad de Salamanca-Spain.

\section{Availability of data and materials}

The datasets used, generated and/or analyzed during the present study are available from the corresponding author upon reasonable request.

\section{Authors' contributions}

$\mathrm{BB}$ and $\mathrm{AP}$ designed the study. $\mathrm{BB}$ and $\mathrm{AE}$ performed the experiments. $\mathrm{BB}$ wrote the manuscript. $\mathrm{BB}$ and $\mathrm{AP}$ contributed to the manuscript revisions.

\section{Ethics approval and consent to participate}

Not applicable.

\section{Patient consent for publication}

Not applicable.

\section{Competing interests}

The authors declare that they have no competing interests. 


\section{References}

1. Feng Y, Spezia M, Huang S, Yuan C, Zeng Z, Zhang L, Ji X, Liu W, Huang B, Liu B, et al: Breast cancer development and progression: Risk factors, cancer stem cells, signaling pathways, genomics, and molecular pathogenesis. Genes Dis 5: 77-106, 2018.

2. Rahman S and Zayed H: Breast cancer in the GCC countries: A focus on BRCA1/2 and non-BRCA1/2 genes. Gene 668: 73-76, 2018.

3. Bai X, Ni J, Beretov J, Graham P and Li Y: Cancer stem cell in breast cancer therapeutic resistance. Cancer Treat Rev 69: 152-163, 2018

4. Assefa B, Glatzel G and Buchmann C: Ethnomedicinal uses of Hagenia abyssinica (Bruce) J.F. Gmel. Among rural communities of Ethiopia. J Ethnobiol Ethnomed 6: 20, 2010.

5. Bouabdelli F, Djelloul A, Kaid-Omar Z, Semmoud A and Addou A: Antimicrobial activity of 22 plants used in urolithiasis medicine in western Algeria. Asian Pac J Trop Dis 2 (Suppl 1): S530-S535, 2012.

6. Azzi R, Djaziri R and Lahfa F: Ethnopharmacological survey of medicinal plants used in the traditional treatment of diabetes mellitus in the North Western and South Western Algeria. J Med Plants Res 6: 2041-2050, 2012.

7. Benarba B, Belabid L, Righi K, Bekkar AA, Elouissi M, Khaldi A and Hammimed A: Ethnobotanical study of medicinal plants used by traditional healers in Mascara (North West of Algeria). J Ethnopharmacol 175: 626-637, 2015.

8. Benarba B: Medicinal plants used by traditional healers from South-West Algeria: An ethnobotanical study. J Intercult Ethnopharmacol 5: 320-330, 2016.

9. Benarba B: Use of medicinal plants by breast cancer patients in Algeria. EXCLI J 14: 1164-1166, 2015.

10. Benarba B, Ambroise G, Aoues A, Meddah B and Vazquez A: Aristolochia longa aqueous extract triggers the mitochondrial pathway of apoptosis in BL41 Burkitt's lymphoma cells. Int J Green Pharm 2012: 45-49, 2012.

11. Benarba B, Pandiella A and Elmallah A: Anticancer activity, phytochemical screening and acute toxicity evaluation of an aqueous extract of Aristolochia longa L. Int J Pharm Phytopharmacol Res 6: 20-26, 2016.

12. Sallam AA, Hitotsuyanagi Y, Mansour ES, Ahmed AF, Gedara $S$, Fukaya $\mathrm{H}$ and Takeya K: Cucurbitacins from Bryonia cretica. Phytochem Lett 3: 117-121, 2010.

13. Nakashima S, Matsuda H, Kurume A, Oda Y, Nakamura S, Yamashita $\mathbf{M}$ and Yoshikawa M: Cucurbitacin E as a new inhibitor of cofilin phosphorylation in human leukemia U937 cells. Bioorg Med Chem Lett 20: 2994-2997, 2010.

14. Matsuda H, Nakashima S, Abdel-Halim OB, Morikawa T and Yoshikawa M: Cucurbitane-type triterpenes with anti-proliferative effects on U937 cells from an egyptian natural medicine, Bryonia cretica: Structures of new triterpene glycosides, bryoniaosides A and B. Chem Pharm Bull (Tokyo) 58: 747-751, 2010.

15. Chekroun E, Bechiri A, Azzi R, Adida H, Benariba N and Djaziri R: Antidiabetic activity of two aqueous extracts of two cucurbitaceae: Citrullus colocynthis and Bryonia dioica. Phytothérapie 15: 57-66, 2017.

16. Dhouioui M, Boulila A, Jemli M, Schiets F, Casabianca H and Zina MS: Fatty acids composition and antibacterial activity of Aristolochia longa L. and Bryonia diö̈a Jacq. Growing wild in tunisia. J Oleo Sci 65: 655-661, 2016.

17. Chekroun E, Benariba N, Adida H, Bechiri A, Azzi R and Djaziri R: Antioxidant activity and phytochemical screening of two Cucurbitaceae: Citrullus colocynthis fruits and Bryonia dioica roots. Asian Pac J Trop Dis 5: 632-637, 2015.

18. Benarba B, Meddah B and Aoues A: Bryonia dioica aqueous extract induces apoptosis through mitochondrial intrinsic pathway in BL41 Burkitt's lymphoma cells. J Ethnopharmacol 141: 510-516, 2012.

19. Díaz-Rodríguez E, Sanz E and Pandiella A: Antitumoral effect of Ocoxin, a natural compound-containing nutritional supplement, in small cell lung cancer. Int J Oncol 53: 113-123, 2018.

20. Díaz-Rodríguez E, El-Mallah AM, Sanz E and Pandiella A: Antitumoral effect of Ocoxin in hepatocellular carcinoma. Oncol Lett 14: 1950-1958, 2017.

21. Sathish S, Janakiraman N and Johnson M: Phytochemical analysis of vitex altissima L. using UV-VIS, FTIR and GC-MS. Int J Pharm Sci Drug Res 4: 56-62, 2012.
22. Rodríguez-GonzaloE,García-GómezD and Carabias-Martínez R Development and validation of a method for the detection and confirmation of biomarkers of exposure in human urine by means of restricted access material-liquid chromatography-tandem mass spectrometry. J Chromatogr A 1217: 40-48, 2010.

23. Roy S, Banerjee B and Vedasiromoni JR: Cytotoxic and apoptogenic effect of Swietenia mahagoni (L.) Jacq. leaf extract in human leukemic cell lines U937, K562 and HL-60. Environ Toxicol Pharm 37: 234-247, 2014.

24. Buranrat B, Mairuae N and Kanchanarach W: Cytotoxic and antimigratory effects of Cratoxy formosum extract against HepG2 liver cancer cells. Biomed Rep 6: 441-448, 2017.

25. Benarba B, Meddah B and Tir-Touil A: Response of bone resorption markers to Aristolochia longa intaked by Algerian breast cancer postmenopausal women. Adv Pharmacol Sci 2014: 1-4, 2014.

26. Sun X, Ma X, Li Q, Yang Y, Xu X, Sun J, Yu M, Cao K, Yang L, Yang G, et al: Anticancer effects of fisetin on mammary carcinoma cells via regulation of the PI3K/Akt/mTOR pathway: In vitro and in vivo studies. Int J Mol Med 42: 811-820, 2018.

27. Piao XM, Gao F, Zhu JX, Wang LJ, Zhao X, Li X, Sheng MM and Zhang Y: Cucurbitacin B inhibits tumor angiogenesis by triggering the mitochondrial signaling pathway in endothelial cells. Int J Mol Med 42: 1018-1025, 2018.

28. Sahpazidou D, Geromichalos GD, Stagos D, Apostolou A, Haroutounian SA, Tsatsakis AM, Tzanakakis GN, Hayes AW and Kouretas D: Anticarcinogenic activity of polyphenolic extracts from grape stems against breast, colon, renal and thyroid cancer cells. Toxicol Lett 230: 218-224, 2014

29. de Lima AP, Pereira Fde C, Vilanova-Costa CA, Soares JR, Pereira LC, Porto HK, Pavanin LA, Dos Santos WB and Silveira-Lacerda Ede P: Induction of cell cycle arrest and apoptosis by ruthenium complex cis-(dichloro)tetramineruthenium(III) chloride in human lung carcinoma cells A549. Biol Trace Elem Res 147: 8-15, 2012.

30. Koo BC, Kim DH, Kim IR, Kim GC, Kwak HH and Park BS: A natural product, chios gum mastic, induces the death of HL-60 cells via apoptosis and cell cycle arrest. Int J Oral Biol 36: 13-21, 2011.

31. Hostanska K, Nisslein T, Freudenstein J, Reichling $\mathbf{J}$ and Saller R: Cimicifuga racemosa extract inhibits proliferation of estrogen receptor-positive and negative human breast carcinoma cell lines by induction of apoptosis. Breast Cancer Res Treat 84: $151-160,2004$

32. Chakravarti B, Maurya R, Siddiqui JA, Bid HK, Rajendran SM, Yadav PP and Konwar R: In vitro anti-breast cancer activity of ethanolic extract of Wrightia tomentosa: Role of pro-apoptotic effects of oleanolic acid and urosolic acid. J Ethnopharmacol 142: 72-79, 2012.

33. Ferreira AK, de-Sá-Júnior PL, Pasqualoto KF, de Azevedo RA, Câmara DA, Costa AS, Figueiredo CR, Matsuo AL, Massaoka MH, Auada AV, et al: Cytotoxic effects of dillapiole on MDA-MB-231 cells involve the induction of apoptosis through the mitochondrial pathway by inducing an oxidative stress while altering the cytoskeleton network. Biochimie 99: 195-207, 2014.

34. Ye B, Li J, Li Z, Yang J, Niu T and Wang S: Anti-tumor activity and relative mechanism of ethanolic extract of Marsdenia tenacissima (Asclepiadaceae) against human hematologic neoplasm in vitro and in vivo. J Ethnopharmacol 153: 258-267, 2014.

35. Lee DH, Park KI, Park HS, Kang SR, Nagappan A, Kim JA, Kim EH, Lee WS, Hah YS, Chung HJ, et al: Flavonoids isolated from Korea citrus aurantium L. induce G2/M phase arrest and apoptosis in human gastric cancer AGS cells. J Evid Based Complementary Altern Med 2012: 1-11, 2012.

36. Zhang Q, Zhao XH and Wang ZJ: Flavones and flavonols exert cytotoxic effects on a human oesophageal adenocarcinoma cell line (OE33) by causing G2/M arrest and inducing apoptosis. Food Chem Toxicol 46: 2042-2053, 2008

37. Gómez-Alonso S, Collins VJ, Vauzour D, Rodríguez-Mateos A, Corona G and Spencer JPE: Inhibition of colon adenocarcinoma cell proliferation by flavonols is linked to a $\mathrm{G} 2 / \mathrm{M}$ cell cycle block and reduction in cyclin D1 expression. Food Chem 130: 493-500, 2012.

38. Youssef Moustafa AM, Khodair AI and Saleh MA: Isolation, structural elucidation of flavonoid constituents from Leptadenia pyrotechnica and evaluation of their toxicity and antitumor activity. Pharm Biol 47: 539-552, 2009.

39. Sisa M, Bonnet SL, Ferreira D and Van der Westhuizen JH Photochemistry of flavonoids. Molecules 15: 5196-5245, 2010. 
40. Tsimogiannis D, Samiotaki M, Panayotou G and Oreopoulou V: Characterization of flavonoid subgroups and hydroxy substitution by HPLC-MS/MS. Molecules 12: 593-606, 2007.

41. Lee HN, Shin SA, Choo GS, Kim HJ, Park YS, Kim BS, Kim SK, Cho SD, Nam JS, Choi CS, et al: Anti-inflammatory effect of quercetin and galangin in LPS-stimulated RAW264.7 macrophages and DNCB-induced atopic dermatitis animal models. Int J Mol Med 41: 888-898, 2018.

42. Romagnolo DF and Selmin OI: Flavonoids and cancer prevention: A review of the evidence. J Nutr Gerontol Geriatr 31: 206-238, 2012

43. Barros L, Dueñas M, Ferreira ICFR, Carvalho AM and Santos-Buelga C: Use of HPLC-DAD-ESI/MS to profile phenolic compounds in edible wild greens from Portugal. Food Chem 127: 169-173, 2011.

44. Marfe G, Tafani M, Indelicato M, Sinibaldi-Salimei P, Reali V, Pucci B, Fini M and Russo MA: Kaempferol induces apoptosis in two different cell lines via Akt inactivation, Bax and SIRT3 activation, and mitochondrial dysfunction. J Cell Biochem 106: 643-650, 2009.

45. Leung HW, Lin CJ, Hour MJ, Yang WH, Wang MY and Lee HZ Kaempferol induces apoptosis in human lung non-small carcinoma cells accompanied by an induction of antioxidant enzymes. Food Chem Toxicol 45: 2005-2013, 2007.

46. Brusselmans K, Vrolix R, Verhoeven G and Swinnen JV: Induction of cancer cell apoptosis by flavonoids is associated with their ability to inhibit fatty acid synthase activity. J Biol Chem 280: 5636-5645, 2005.

47. Kang JW, Kim JH, Song K, Kim SH, Yoon JH and Kim KS Kaempferol and quercetin, components of Ginkgo biloba extract (EGb 761), induce caspase-3-dependent apoptosis in oral cavity cancer cells. Phytother Res 24 (Suppl 1): S77-S82, 2010.

48. Devi KP, Rajavel T, Habtemariam S, Nabavi SF and Nabavi SM: Molecular mechanisms underlying anticancer effects of myricetin. Life Sci 142: 19-25, 2015.

49. Kim ME, Ha TK, Yoon JH and Lee JS: Myricetin induces cell death of human colon cancer cells via BAX/BCL2-dependent pathway. Anticancer Res 34: 701-706, 2014

50. Xu Y, Xie Q, Wu S, Yi D, Yu Y, Liu S, Li S and Li Z: Myricetin induces apoptosis via endoplasmic reticulum stress and DNA double-strand breaks in human ovarian cancer cells. Mol Med Rep 13: 2094-2100, 2016.
51. Zheng AW, Chen YQ, Zhao LQ and Feng JG: Myricetin induces apoptosis and enhances chemosensitivity in ovarian cancer cells. Oncol Lett 13: 4974-4978, 2017.

52. Morales P and Haza AI: Selective apoptotic effects of piceatannol and myricetin in human cancer cells. J Appl Toxicol 32: 986-993, 2012.

53. Zhang S, Wang L, Liu H, Zhao G and Ming L: Enhancement of recombinant myricetin on the radiosensitivity of lung cancer A549 and H1299 cells. Diagn Pathol 9: 68, 2014.

54. de Oliveira Júnior RG, Christiane Adrielly AF, da Silva Almeida JRG, Grougnet R, Thiéry V and Picot L: Sensitization of tumor cells to chemotherapy by natural products: A systematic review of preclinical data and molecular mechanisms. Fitoterapia 129: 383-400, 2018.

55. Lu J, Papp LV, Fang J, Rodriguez-Nieto S, Zhivotovsky B and Holmgren A: Inhibition of mammalian thioredoxin reductase by some flavonoids: Implications for myricetin and quercetin anticancer activity. Cancer Res 66: 4410-4418, 2006.

56. Maggioni D, Nicolini G, Rigolio R, Biffi L, Pignataro L, Gaini R and Gravello W: Myricetin and naringenin inhibit human squamous cell carcinoma proliferation and migration in vitro. Nutr Cancer 66: 1257-1267, 2014.

57. Deepa M, Sureshkumar T, Satheeshkumar PK and Priya S: Antioxidant rich Morus alba leaf extract induces apoptosis in human colon and breast cancer cells by the downregulation of nitric oxide produced by inducible nitric oxide synthase. Nutr Cancer 65: 305-310, 2013.

58. Jayakumar JK, Nirmala P, Praveen Kumar BA and Kumar AP: Evaluation of protective effect of myricetin, a bioflavonoid in dimethyl benzanthracene-induced breast cancer in female Wistar rats. South Asian J Cancer 3: 107-111, 2014.

59. Semwal DK, Semwal RB, Combrinck S and Viljoen A: Myricetin: A dietary molecule with diverse biological activities. Nutrients 8: 90, 2016.

60. Martínez-Pérez C, Ward C, Turnbull AK, Mullen P, Cook G, Meehan J, Jarman EJ, Thomson PI, Campbell CJ, McPhail D, et al: Antitumour activity of the novel flavonoid Oncamex in preclinical breast cancer models. Br J Cancer 114: 905-916, 2016. 